\title{
Awareness and Implementation of Career Development Plan towards Job Performance and Satisfaction of Employees
}

\author{
Ramil S. Bulilan
}

Research and Development, and Extension Unit, Bohol Island State University, Clarin Campus, Clarin, Bohol, Philippines

Received: 30 Sept 2020; Received in revised form: 18 Nov 2020; Accepted: 22 Nov 2020; Available online: 28 Nov 2020

(C)2020 The Author(s). Published by Infogain Publication. This is an open access article under the CC BY license

(https://creativecommons.org/licenses/by/4.0/).

\begin{abstract}
This study investigated the relationship of Bohol Island State University (BISU) employees' awareness and implementation levels of their Career Development Plan (CDP)on their job performance and satisfaction. Using descriptive-survey in a quantitative-correlational approach and universal sampling, it surveyed 345 regular BISU employees. Specifically, it identified the respondents' demographic profile, their job performance, and job satisfaction, and determined the relationships of their awareness and job performance, awareness and job satisfaction, implementation and job performance, and performance and satisfaction. Findings revealed that respondents were in their young adulthood stage, dominated by females, experienced employees, and highly educated. They did not have enough knowledge of CDP of BISU, perceived it a bit implemented, performed well in their duties, and were somewhat satisfied with their jobs. Employment experience indicated significant results on job performance and satisfaction, implying that the longer their stay in BISU, the better their performance, and the more satisfied they become. Moreover, implementation and job satisfaction showed significant results, meaning the respondents consider the significance and urgency of implementing whatever career plans and programs beneficial for both of employees and the organization. Henceforth, it indicates that proper implementation of the planned career growth would make the workers more satisfied with their jobs.
\end{abstract}

Keywords-employees' awareness, implementation levels, job performance and satisfaction, Philippines, quantitative correlation.

\section{INTRODUCTION}

Career Development Plan (CDP)is considered of great importance to both employer and employee. It plays some critical roles in an organization or in an institution. As a written list of the short and long-term goals for employees' current and future jobs, and a planned sequence of formal and informal experiences, it assists employees in achieving their goals and helps them grow not only professionally but also personally (Heathfield, 2019).For Trueba (2008), properly implemented plan can help the manager focus on supporting employees in gaining new skills, while adding value to their organizations. It also helps employees stay on track and move forward in their careers.

The CDP of Bohol Island State University (BISU)was approved by the Civil Service Commission in Region VII on January 17, 2012 and was implemented thereafter. The said Plan was intended for all BISU System Officials and Employees (BISU Career Development Plan, 2012). This plan stipulates the policy goals, general guidelines, creation and statements of functions of Career and Personnel Development Committee, career development opportunities, availment guidelines, support mechanism, its effectivity, and the proposed integrated human resource

ISSN: $2456-7620$ 
development program. However, as observed, not all employees are aware of it nor its implementation. Thus, the researcher was triggered to conduct an investigation to determine the employees' level of awareness and extent of implementation of such CDP and its impact towards their job performance and satisfaction. Initial data gathered from the researcher's casual talk with fellow BISU employees suggest the very significant role that Career Development Plan plays in their stay in this institution. Besides, there are no studies conducted dealing with the same nature of this present investigation. Thus, the results of this study would contribute to the body of literature for future reference.

The CSC mandates the establishment of a program on career development and management in every department or agency as specified in the Implementing Rule VIII, under Book V EO 292 of the Civil Service Law. This makes the indispensability of crafting and implementing a Career Development Plan in Bohol Island State University for both employer and employees' perspectives and welfare.

Article II, Sec. 4 of RA 10912 states that there shall be formulated and implemented Continuing Professional Development Programs in each of the regulated professions in order to enhance and upgrade the competencies and qualifications of professionals for the practice of their professions, and to ensure international alignment of competencies and qualifications of professionals through career progression mechanisms leading to specialization. Again, every career development should be geared towards employees' welfare and satisfaction.

Career development plan maps out the necessary activities, within the projected timeframe and resources needed, to develop and enhance the competencies needed by an individual in pursuit of the envisioned career path. Career path is a defined track of development activities that an individual follows in pursuit of professional goals (DSWD's Memo Circular No. 5, s. 2007).

In an institution of higher learning such as Bohol Island State University, crafting and implementing a Career Plan of Action is deemed very essential in the lives of both employer and employees. Equally important is employees' conscious knowledge about its existence and its implementation.

For Heathfield (2019), a career development plan in place is a win for employers and employees. Its plan focuses on the employees' needs for growth and development and the assistance the organization can provide so that the employee has the opportunity to grow his or her career. In addition to growing their career, employees are also interested in developing themselves both personally and professionally. To Zin, Shamsudin and Subramaniam, (2013), career development activities can help employees discover their vocational interests and strengths, while employers can make it as a way to attract the best employees and retain them over time.

Employees are one of the important tools of any organization (Gabčanová, 2011) and their development is considered as an important factor for organizational growth (Mutonga, 2012). Thus, any plan or program is said to be successful if it positively affects the employees (Kumar, 2016).

This study is based on the theories by Super, Adams, and Herzberg. In Donald E. Super's Life Career Rainbow Theory (1980), it described career development in terms of life stages and life roles that reflected a rainbow. The life roles were shown in the colored stripes of the rainbow where age was written with numbers under these stripes. The size of the dots in the colored stripes indicated the time that took a life role up. Career development can be analyzed based on the career stages. There are five career development stages through which most of us have gone through or will go through (Mulder, 2019). Further, according to Super et al. (1996) as cited by Kosine, and Lewis, (2008), this theory is a combination of stage development and social role theory which posits that people progress through five stages during the career development process, including growth, exploration, establishment, maintenance, and disengagement.

Adam's Equity Theory (1963) posits that people maintain a fair relationship between the performance and rewards in comparison to others. In other words, an employee gets de-motivated by the job and his employer in case his inputs are more than the outputs (Business Jargon). Thus, an individual's level of motivation depends on the extent he feels being treated fairly, in terms of rewards, in comparison to others. Thus, according to Al-zawahreh and Madi, 2012), equity theory predicts that low rewards produce dissatisfaction; this would in turn motivate people to take action and reduce the discrepancy between their ratio and the ratio of the comparison other.

In addition, in 1976, Herzberg's Two Factor Theory was conceived. According to this theory, factors such as recognition, accomplishment, responsibility, promotion were 
treated as motivator factors, while policy and administration, supervision, interpersonal relationship, working conditions, salary, status, and security were treated as the hygiene factors. The motivating factors are those aspects of the job that make people want to perform well and thus provide them with job satisfaction (Tan \&Waheed, 2011).

At any rate, awareness of something very significant to someone is indeed an interesting endeavor to delve into most especially if such would impact his/her career. Thus, an initialstep of this attempt is to determine the awareness level of the employees about this Career Development Plan of BISU, then anattempt also to determine whether such plan was implemented or not must follow. Awareness can be considered as a concept referring to the ability of a person to perceive, to feel, or to directly aware of any events (Nifa, et al., 2018). However, evaluating employees' awareness of their career development is not enough. Employees should also be asked whether such plan is implemented or not.

Implementation, according to Gustafson (2019), is the process of executing a plan or policy so that a concept becomes a reality. To implement a plan properly, managers should communicate clear goals and expectations, and supply employees with the resources needed to help the company achieve its goals. He further insisted that the implementation of a plan brings about change meant to help improve the company or solve a problem on policies, management structures, organizational development, budgets, processes, products or services.

How any approved Career Development Plan relates on the job performance and enhances one's satisfaction level is also an area of concern of this study. Job performance can be defined as all the behaviors employees engage in while at work. Individual job performance is a relevant outcome measure of studies in the occupational setting; it refers to how well someone performs at his or her work (Fogaça, Rego, Melo, Armond, \& Coelho, 2018).

On the other side, job satisfaction is an important factor in an organization's success (Tan \& Waheed, 2015). It is a topic that has received considerable attention by researchers and practitioners (Bhatnagar, \& Srivastava, 2012). It is simply how people feel about their jobs. It is the extent to which people like (satisfaction) or dislike (dissatisfaction) their jobs. It can also be a reflection of good treatment and an indicator of emotional well-being (Spector, 1997). It is the level to which workers like their work, and the difference between what employees' expectation and what they receive, and for Omori \& Bassey, (2019), it is a reflection of good treatment and an indicator of emotional well-being.

Although a plethora of studies has been conducted about job performance and job satisfaction (Ezeamama, 2019; Satar, Nawaz, \& Khan, 2012;Anuar, 2011), which showed positive results, there were also studies which yielded the otherwise (Ram, 2013). Hence, there is a need to conduct more studies on job satisfaction and performance of employees since an employee is believed to be an indispensable part of an organization.

Whether career development plan has something to with employees' job satisfaction, a study was conducted by Jusuf, Mahfudnurnajamuddin, Mallongi, and Latief, (2016) on the effect of career development, leadership style and organizational culture on job satisfaction and organizational commitment. Results proved positive and influenced career development significantly to job satisfaction Shujaat, et al., 2013; Chen et al., 2004) The statement meant that a good career development provides a tangible influence against employee job satisfaction. This result has given the implication that the employee career development has significantly influenced employees' job satisfaction.

This present endeavor attempted also to delve into exploring whether or not demographic characteristics on age, sex, educational attainment, and length of service components of employees have something to do with their job performance, and satisfaction. Studies of Ugwu and Ugwu, (2017)found that work experience was significant and positively correlated of job performance of librarians in Nigeria; whereas, a study conducted by Shrestha, (2019), and Barotik, (2016) indicated a positive relationship between length of service and job performance.

As to gender, it had a negative significant relationship with workers' performance (Omori, et al., 2019). Following this result, both male and female trained on the same job do performed alike. It therefore means that if male and female are given equal opportunities on any task's performance in the public service, there is bound to be a progressive improvement as both can deliver as same. $\mathrm{Ng}$ and Feldman (2009) argued against age as a determinant factor to performance. They say that age is a very weak predictor of performance. 


\section{Objectives}

This study aimed primarily at determining the employees' awareness and implementation levels of Career Development Plan(CDP)s of Bohol Island State University in relation to their job performance and satisfaction levels. Specifically, it determined respondents' demographic profile in terms of age, sex, educational attainment, and length of service in this institution; the respondents' perception as to their level of awareness of the CDP; extent of implementation of CDP; level of job performance; extent of job satisfaction; the significant relationship between the demographic profile and their job performance; demographic profile and their job satisfaction; the significant relationship between their levels of awareness and job performance and satisfaction and levels of implementation and job performance and satisfaction. With the results, a doable action plan was designed as enhancement of the existing Career Development Plan of BISU.

\section{METHODOLOGY}

This study used a descriptive-correlational research utilizing a set of structured and closed-ended questionnaires administered to the 345 regular employees from the six campuses of Bohol Island State University - Balilihan, Bilar, Calape, Candijay, Clarin, and Tagbilaran City, the Main Campus. Universal sampling technique was employed. However, the problem in the retrieval of the duly accomplished questionnaires occurred in Bilar and Tagbilaran Campuses where some of the respondents failed to return said questionnaires, refused to answer them, without Individual Performance Commitment and Review (IPCR) ratings, and some invalid responses. The results of their IPCR ratings in 2018 were considered as the job performance of employees.

A total of 345 regular BISU employees across its six campuses comprise the respondents of this study. They were broken down as follows: 261faculty members, 68 nonteaching personnel, and 16management personnel. Management personnel here, as research respondents, refer to the six (6) Campus Directors of each campus, five (5) Administrative Officers, and five (5) other heads of departments from Tagbilaran City-Main Campus. They were further broken down as follows: Balilihan Campus with24 respondents $(7 \%$,$) , Bilar Campus with 73$ (21\%), Calape Campus with 35 (10\%), Candijay Campus with 66 (19\%),
Clarin Campus with 47 (14\%), and Tagbilaran City-Main Campus has 100 (29\%) respondents.

The instruments used for data collection were the Respondents' Demographic Survey, the Evaluation Survey of the approved Career Development Plan of BISU as to the extent of each employee's awareness and implementation, the summary results of ratings of the 2018 Individual Performance Commitment and Review, and the Job Satisfaction Survey (JSS) adopted from Spector (1994). These tools were devised and used in order to address all the problems under investigation.

Since the Evaluation Survey of the approved Career Development Plan of BISU was self-directed tool, it was pilot-tested to 33 non- permanent employees in BISU Calape and Clarin campuses. The final draft was distributed to the respondents after having revised it adhering to the results of the dry-run.

The Job Satisfaction Survey was used in determining their job satisfaction level. The tool used was the Job Satisfaction Survey adopted from Paul E. Spector in 1994. Such tool is a 36 item, nine-facet scales to assess employee attitudes about the job and aspects of the job. Each facet is assessed with four items. Using the 6-point Likert scale, 6 as "strongly agree" down to 1 as "strongly disagree", the respondents were asked to rate on the extent of their satisfaction of the jobs based on the nine facets, such are pay, promotion, supervision, fringe benefits, contingent rewards (performance-based rewards), operating procedures (required rules and procedures), coworkers, nature of work, and communication.

As a preliminary activity and part of research protocol and ethics, the researcher secured an informed consent from the respondents prior to the administration of the tools to the six campuses of BISU. A letter of request approved by the University President regarding administration of the research tools was attached to the informed consent. Then the actual personal distribution of questionnaires commenced which lasted for about a week. The researcher was able to retrieve enough number of valid and duly accomplished questionnaires. This could have lasted for more than a month, had it not without the assistance of the Campus Director in Candijay, secretaries of colleges, administrative officers, and some friends, which took for a month only.

All computations were done using Microsoft excel. In getting the demographic profile of the respondents, specifically in terms of their age, sex, educational 
attainment, and length of service in this institution, percentage formula was used. In identifying the respondents' level of awareness, extent of implementation of CDP 2012, job performance level, and extent of job satisfaction, the weighted mean formula was used.

\begin{tabular}{|c|c|c|}
\hline Scales & Responses & Interpretations \\
\hline $5(4.20-5.00)$ & $\begin{array}{l}\text { Very Much Aware } \\
\text { (VMA) }\end{array}$ & Totally aware of all programs and activities stipulated in CDP \\
\hline $4(3.40-4.19)$ & Much Aware (MA), & Aware of almost all programs and activities of the CDP \\
\hline $3(2.60-3.39)$ & Aware (A) & Aware of most of the programs and activities of the CDP \\
\hline $2(1.80-2.59)$ & Slightly Aware (SA) & aware of only some of the programs and activities of the CDP \\
\hline $1(1.00-1.79)$ & Not Aware (NA) & $\begin{array}{l}\text { Totally unaware of all the programs and activities stipulated in } \\
\text { CDP }\end{array}$ \\
\hline
\end{tabular}

Herewith are the scales, responses, and interpretation for the extent of implementation:

\begin{tabular}{|c|c|c|}
\hline Scales & Responses & Interpretations \\
\hline $6(5.16-6.00)$ & Highly Implemented (HI) & All of the programs/activities stipulated in CDP are implemented properly \\
\hline $5(4.32-5.15)$ & Implemented (I) & $\begin{array}{l}\text { Almost all of the programs and activities stipulated in CDP are } \\
\text { implemented }\end{array}$ \\
\hline $4(3.49-4.31)$ & Moderately Implemented (MI) & Some of the programs and activities stipulated in CDP are implemented \\
\hline $3(2.66-3.48)$ & Slightly Implemented (SI) & $\begin{array}{l}\text { Very few of the programs and activities stipulated in CDP are } \\
\text { implemented }\end{array}$ \\
\hline $2(1.83-2.65)$ & Not Implemented (NI) & None of the programs and activities stipulated in CDP is implemented \\
\hline $1(1.00-1.82)$ & $\begin{array}{l}\text { No knowledge if implemented } \\
\text { or not }(\mathrm{NK})\end{array}$ & Do not know if such item is implemented or not \\
\hline
\end{tabular}

For Job Performance, the scale following was based on Civil Service Commission Memorandum Circular No. 06, s. 2012 setting the guidelines on the establishment and implementation of the Strategic Performance Management System (SPMS) in all government agencies.

\begin{tabular}{|c|c|c|}
\hline Scales & Responses & Interpretation \\
\hline $5(4.20-5.00)$ & Outsta & $\begin{array}{l}\text { Performance represents an extraordinary level of achievement and commitment in terms of } \\
\text { quality and time, technical skills and knowledge, ingenuity, creativity and initiative. } \\
\text { Employees at this performance level should have demonstrated exceptional job mastery in } \\
\text { all areas of responsibility. Employee achievement and contributions to the organizations } \\
\text { are of marked excellence. }\end{array}$ \\
\hline $4(3.40-4.19)$ & $\begin{array}{l}\text { Very } \\
\text { Satisfactory }\end{array}$ & $\begin{array}{l}\text { Performance exceeded expectations. All goals, objectives and target were achieved above } \\
\text { the established standards. }\end{array}$ \\
\hline $3(2.60-3.39)$ & Satisfactory & $\begin{array}{l}\text { Performance met expectations in terms of quality of work, efficiency and timeliness. The } \\
\text { most critical annual goals were met. }\end{array}$ \\
\hline $2(1.80-2.59)$ & Unsatisfactory & Performance failed to meet expectations, and/or one or more of the most goals were not \\
\hline
\end{tabular}


met.

1(1.00-1.79) Poor Performance was consistently below expectations, and/or reasonable progress toward critical goals was not made. Significant improvement is needed in one or more important areas.

For Job Satisfaction, herewith are the scales, responses, and interpretations:

\begin{tabular}{lll}
\hline Scales & Responses & Interpretations \\
\hline $6(5.16-6.00)$ & Strongly Agree (SA) & Extremely satisfied (ES) \\
$5(4.32-5.15)$ & Moderately Agree (MA) & Very satisfied (VS) \\
$4(3.49-4.31)$ & Slightly Agree (SlA) & Somewhat satisfied (SS) \\
$3(2.66-3.48)$ & Slightly Disagree (SID) & Somewhat dissatisfied (SD) \\
$2(1.83-2.65)$ & Moderately Disagree (MD) & Very dissatisfied (VD) \\
$1(1.00-1.82)$ & Strongly Disagree (SD) & Extremely dissatisfied (ED) \\
\hline
\end{tabular}

High scores on the scale represent job satisfaction, so the scores on the negatively worded items were reversed first before computing using the said formula assuming with the positively worded into facet or total scores. A score of 6 representing strongest agreement with a negatively worded item is considered equivalent to a score of 1 representing strongest disagreement on a positively worded item, allowing them to be combined meaningfully. Thus, this means that scores with a mean item response (after reverse scoring the negatively-worded items) of 4 or more represents satisfaction, whereas mean responses of 3 or less represents dissatisfaction. Mean scores between 3 and 4 are ambivalence (Spector, 1994).

In determining the significant relationship between the demographic profile and level of job performance; and extent of job satisfaction levels, the chi-square test was used. For the significant correlation between the level of two variables such as awareness and job performance, awareness and job satisfaction, implementation and job performance, implementation and job satisfaction, job performance and job satisfaction, Spearman's rho was computed.

\section{III. RESULTS AND DISCUSSION}

Table 1. Demographic Profile of Respondents

$\mathrm{N}=345$

\begin{tabular}{|c|c|c|c|}
\hline Age & Frequency & Percentage & Rank \\
\hline 21 and below years old & 0 & 0 & 12 \\
\hline $22-25$ years old & 27 & 7.83 & 7 \\
\hline 26-29 years old & 49 & 14.20 & 1 \\
\hline $30-33$ years old & 38 & 11.01 & 4.5 \\
\hline 34-37 years old & 46 & 13.33 & 2 \\
\hline $38-41$ years old & 42 & 12.17 & 3 \\
\hline $42-45$ years old & 38 & 11.01 & 4.5 \\
\hline 46-49 years old & 29 & 8.41 & 6 \\
\hline 50-53 years old & 23 & 6.67 & 8.5 \\
\hline
\end{tabular}




\begin{tabular}{|c|c|c|c|}
\hline 54-57 years old & 21 & 6.09 & 10 \\
\hline 58-61 years old & 23 & 6.67 & 8.5 \\
\hline 62 and up years old & 9 & 2.61 & 11 \\
\hline Total & 345 & 100.0 & \\
\hline \multicolumn{4}{|l|}{ Sex } \\
\hline Male & 150 & 43.48 & 2 \\
\hline Female & 195 & 56.52 & 1 \\
\hline Total & 345 & 100.0 & \\
\hline \multicolumn{4}{|c|}{ Educational Attainment } \\
\hline Bachelor's Degree & 41 & 11.88 & 4.5 \\
\hline With MA/MS Units & 41 & 11.88 & 4.5 \\
\hline Master's Degree & 86 & 24.93 & 2 \\
\hline With Doctoral Units & 88 & 25.51 & 1 \\
\hline Doctorate & 73 & 21.16 & 3 \\
\hline Others & 16 & 4.64 & 6 \\
\hline Total & 345 & 100.0 & \\
\hline \multicolumn{4}{|l|}{ Length of Service } \\
\hline Less than a year & 7 & 2.03 & 10 \\
\hline $1-3$ years & 66 & 19.13 & 2 \\
\hline 4-7 years & 65 & 18.84 & 3 \\
\hline $8-11$ years & 73 & 21.16 & 1 \\
\hline $12-15$ years & 34 & 9.86 & 5 \\
\hline $16-19$ years & 37 & 10.72 & 4 \\
\hline $20-23$ years & 13 & 3.77 & 7.5 \\
\hline 24-27 years & 16 & 4.64 & 6 \\
\hline 28-31 years & 13 & 3.77 & 7.5 \\
\hline $32-35$ years & 11 & 3.19 & 9 \\
\hline $36-39$ years & 6 & 1.74 & 11 \\
\hline 40 and up years & 4 & 1.15 & 12 \\
\hline Total & 345 & 100 & \\
\hline
\end{tabular}

Result shows that 49 respondents $(14.20 \%)$ are in their $26-29$ years old; 46 or $13.33 \%$ are $38-41$ years old, and $42(12.17 \%)$ are within $34-37$ years in age brackets. This implies that they are in their young adulthood life stage in career development where an individual is settled, a family is founded, a study program has been completed, and a permanent job has been found. Taking responsibility and personal satisfaction from work are characteristic of this phase (Mulder, 2019).

As to sex, it reveals that female respondents, 195 or $56.52 \%$, are more in number than males (150 or $43.48 \%$ ). The result supports to the study of Sarker, Crossman, and Chinmeteepituck, (2003). 
The educational attainment of the respondents showed that employees with doctoral units rank number 1 , with 88 or $25.51 \%$, which is followed by those respondents who are master's degree holders with 86 or $24.93 \%$, and holders of doctoral degrees with 73 of them or $21.16 \%$. These data are the offshoot of CHED's upholding of the issued Revised Manual of Regulations for private schools by the then Department of Education in 1992 which required college faculty members to have a master's degree as a minimum educational qualification for acquiring regular status.
Moreover, the above data shows a larger portion of the respondents have spent between 8-11 years in service here in BISU representing about $21.16 \%$, which is followed by $6619.13 \%$ ) who have spent $1-3$ years, and 65 (18.84\%)with 4-7 years. This implies that majority are already seasoned employees. This finding is similar with Odhiambo, Gachoka, and Rambo (2018) where majority of the respondents had worked for the organizations between 10 and 14 years which they considered them as experienced employees.

Table 2. Level Awareness and Extent of Implementation of Career Development Plan of BISU

\begin{tabular}{|c|c|c|c|c|}
\hline & \multicolumn{2}{|c|}{ Level of Awareness } & \multicolumn{2}{|c|}{ Extent of Implementation } \\
\hline Items about Career Development Plan 2012 of BISU & $\begin{array}{l}\begin{array}{l}\text { Weight } \\
\text { ed }\end{array} \\
\text { Mean }\end{array}$ & $\begin{array}{c}\text { Descriptive } \\
\text { Value }\end{array}$ & $\begin{array}{c}\text { Weighted } \\
\text { Mean }\end{array}$ & $\begin{array}{c}\text { Descriptive } \\
\text { Value }\end{array}$ \\
\hline 1. There is a CDP of BISU 2012, a manual... & 2.33 & Slightly Aware & 2.63 & Not Implemented \\
\hline 2. The CDP was approved on $1 / 17 / 2012$ by the CSC $\ldots$ & 2.05 & Slightly Aware & 2.51 & Not Implemented \\
\hline 3. Such CDP was implemented right after its approval. & 1.86 & Slightly Aware & 2.33 & Not Implemented \\
\hline 4. There was created a CPDC... & 1.90 & Slightly Aware & 2.28 & Not Implemented \\
\hline Composite Mean & 2.03 & Slightly Aware & 2.44 & Not Implemented \\
\hline 5. A systematic and planned career program on long and... & 2.29 & Slightly Aware & 2.66 & Not Implemented \\
\hline 6. Availment of all human resource development... & 2.50 & Slightly Aware & 2.92 & Slightly Implemented \\
\hline 7. The BISU System shall utilize a mutually... & 2.32 & Slightly Aware & 2.77 & Slightly Implemented \\
\hline 8. Promotion of employees as an integral part... & 2.92 & Aware & 3.46 & Slightly Implemented \\
\hline 9. Rewards and incentives for both individual.. & 3.29 & Aware & 3.87 & Moderately Implemented \\
\hline 10.Scholars' responsibilities shall be guided by... & 2.57 & Slightly Aware & 3.21 & Slightly Implemented \\
\hline 11. Scholars under the BISU System Welfare Fund shall... & 2.34 & Slightly Aware & 2.92 & Slightly Implemented \\
\hline 12. The BISU System HRMO... & 2.51 & Slightly Aware & 2.99 & Slightly Implemented \\
\hline Composite Mean & 2.47 & Slightly Aware & 3.10 & Slightly Implemented \\
\hline 13. Pursuant to Sec.14, Rule VIII of Bk V of EO No. 292. & 2.32 & Slightly Aware & 2.73 & Slightly Implemented \\
\hline 14. Master in Public Administration (MPA-UP), MATVE.. & 1.91 & Slightly Aware & 2.32 & Not Implemented \\
\hline 15. HRM Financial Mgt. Information Tech., Performance & 1.89 & Slightly Aware & 2.32 & Not Implemented \\
\hline 16. Specialized conferences for management, World ... & 2.08 & Slightly Aware & 2.48 & Not Implemented \\
\hline 17. Public Service Ethics \& Accountability, Basic ... & 2.33 & Slightly Aware & 2.68 & Slightly Implemented \\
\hline 18. Basic Software Operation Course, Data Analysis and... & 2.51 & Slightly Aware & 2.92 & Slightly Implemented \\
\hline 19. Organization Development, Role Analysis, ... & 2.63 & Aware & 3.12 & Slightly Implemented \\
\hline Composite Mean & 2.23 & Slightly Aware & 2.65 & Not Implemented \\
\hline 20. Academic scholarship may be availed of only after at... & 2.54 & Slightly Aware & 3.16 & Slightly Implemented \\
\hline
\end{tabular}


21.Scholarship for master's programs shall preferably be...

22. Scholarship, training courses, or conferences held...

23. Locally held scholarship, training courses, or...

24. BISU System employees with salary grade 26 and up...

25. Short-term courses, conferences, professional...

26. Incumbents of Senior/Higher Admin Positions...

27. Attendance in BISU System Orientation course, ...

28. Other short-term courses as described in the BISU...

29. Employees may be eligible for scholarship under...

30. Job Rotation. It shall be a management-driven...

31. Only those with satisfactory ratings shall be...

32. Sabbatical Leaves. Thesemay be enjoyed by third...

33. Coaching. This is a mechanism for developing...

34. Reassignment to any Campus or office within...

35. Mentoring. This shall be encouraged for employees ...

36. Counseling. This shall be utilized in dealing with...

37. Socialization/Team Building Activities. These ...

38. There shall be established and maintained ...

39.A Career Resource Unit (CRU)shall be set up within...

40. A pool of internal counselors shall be created to...

41. All campus Directors, Heads of Units/Divisions...

42. Five (5\%) percent of the total personnel budget shall...

43. Appropriation for the Consultation Mechanism shall ...

44. There is a proposed Integrated Human Resource...

\section{Composite Mean}

2.48

1.98

2.01

1.79

2.36

1.77

2.70

2.11

2.12

2.27

1.91

2.11

2.35

2.13

2.56

2.59

3.55

2.30

2.37

2.16

2.05

2.71

2.25

2.14

2.23

2.27

Composite Mean

Overall Composite Mean
2.27

2.27
Slightly Aware

Slightly Aware

Slightly Aware

Not Aware

Slightly Aware

Not Aware

Aware

Slightly Aware

Slightly Aware

Slightly Aware

Slightly Aware

Slightly Aware

Slightly Aware

Slightly Aware

Slightly Aware

Slightly Aware

Much Aware

Slightly Aware

Slightly Aware

Slightly Aware

Slightly Aware

Aware

Slightly Aware

Slightly Aware

Slightly Aware

Slightly Aware

Slightly Aware

\subsection{7}

2.36

2.38

2.10

2.83

2.13

3.28

2.63

2.63

2.77

2.37

2.49

2.82

2.66

2.99

3.06

4.13

2.76

2.74

2.58

2.46

2.99

2.69

2.50

2.61

2.65

2.72
Slightly Implemented

Not Implemented

Not Implemented

Not Implemented

Slightly Implemented

Not Implemented

Slightly Implemented

Not Implemented

Not Implemented

Slightly Implemented

Not Implemented

Not Implemented

Slightly Implemented

Not Implemented

Slightly Implemented

Slightly Implemented

Moderately Implemented

Slightly Implemented

Slightly Implemented

Not Implemented

Not Implemented

Slightly Implemented

Slightly Implemented

Not Implemented

Not Implemented
The data here show that all of the six components of the CDP Manual 2012 are rated by the respondents as "slightly aware", with the composite means of $2.03,2.47$, $2.32,2.23,2.30$, and 2.27, respectively. Moreover, 36 out of 44 items are rated as "slightly aware", with the composite mean of 2.27. This means that the respondents are aware of only some of the programs, activities, and items stipulated in CDP. This further implies that BISU employees do not have enough awareness or knowledge of the existence of the said CDP. It is interesting to note that item \#24 which states that "BISU System employees with salary grade 26 and up shall no longer be eligible for any foreign or local scholarships", and item \#26 stating that "Incumbents of Senior/Higher Admin Positions performing the functions of a lawyer shall undergo a technical legal writing course" are rated "not aware". This means that they do not know anything about these items. Only one item, \#37 on "Socialization/Team Building Activities" is rated as "much aware".

In the whole scheme, it can be construed that there was no enough dissemination about this CDP of BISU considering that no one rated "very much aware" of any item about the Plan. According to Tolle, (2005), awareness offers 
more than just hope, but more willingly, it can to lead to action. It is the greatest agent for change. So, there should be an orientation or reorientation to this effect for awareness, guidance, and information about such Plan.

On the respondent's perceived extent of implementation of the said CDP, 3 of the 6 components of the CDP evaluated are rated as "not implemented". They are "On the Career Development Plan 2012 of BISU Itself", with a composite mean of 2.44; "On the Career Development Opportunities/Types of Scholarship", with a composite mean of 2.65; and,"On Support Mechanism, Etc.", with a composite mean of 2.65. Subsequently, none of the items is rated "implemented", "highly implemented", and "no knowledge if the item was implemented or not".
Surprisingly, 21 items are rated as "not implemented" 21 items are rated as "slightly implemented", and 2 items are rated as "moderately implemented".

Thus, the implementation level of CDP as perceived by the respondents is "slightly implemented" with an overall composite mean of 2.76 . This simply connotes that only very few of the programs and activities in the Plan were implemented. Again, this result implies that the CDP 2012 of BISU is not fully implemented. For Trueba (2008), properly implemented plan can help the manager focus on supporting employees in gaining new skills, while adding value to their organizations. It also helps employees stay on track and move forward in their careers.

Table 3. Job Performance of Respondents

$\mathrm{N}=345$

\begin{tabular}{lccccccccc}
\hline \multicolumn{1}{c}{ Job Performance } & \multicolumn{2}{c}{ Management } & \multicolumn{2}{c}{ Faculty } & \multicolumn{2}{c}{ Non-teaching } & \multicolumn{2}{c}{ Rank } \\
& Male & Female & Male & Female & Male & Female & Total & & \\
\hline Outstanding & 3 & 4 & 3 & 8 & 1 & 0 & 19 & 5.51 & 2 \\
V-Satisfactory & 3 & 6 & 103 & 143 & 34 & 32 & 321 & 93.04 & 1 \\
Satisfactory & 0 & 0 & 2 & 2 & 1 & 0 & 5 & 1.45 & 3 \\
Unsatisfactory & 0 & 0 & 0 & 0 & 0 & 0 & 0 & 0 & 4.5 \\
Poor & 0 & 0 & 0 & 0 & 0 & 0 & 0 & 0 & 4.5 \\
\hline Total & 6 & 10 & 108 & 153 & 36 & 32 & $\mathbf{3 4 5}$ & $\mathbf{1 0 0 . 0}$ \\
& \multicolumn{8}{c}{ Overall Performance: $3.72=$ Very Satisfactory } \\
\hline
\end{tabular}

Data in this table show that 321 respondents or 93.04\% are "Very Satisfactory", 19 (5.51\%) are "Outstanding", and the rest (5 or 1.45\%) are "Satisfactory". Over-all, their job performance level is "very satisfactory" with a weighted mean of 3.72. No one is rated "unsatisfactory" and "poor". This implies that the performance of BISU employees has exceeded expectations, and that all goals, objectives, and target were achieved above the established standards. In other words, they are performing well in their tasks since this is expected of them as government servants in an institution of higher learning.

Table 4. Job Satisfaction of Respondents

\begin{tabular}{lcc}
\hline \multicolumn{1}{c}{ Items } & Weighted Mean & Descriptive Value \\
\hline 1. I feel I am being paid a fair amount for the work I... & 4.62 & Very Satisfied \\
*2. There is really too little chance for promotion on my... & 4.01 & SomewhatSatisfied \\
3. My supervisor is quite competent in doing his/her job. & 4.73 & Very Satisfied \\
*4. I am not satisfied with the benefits I receive. & 4.34 & Very Satisfied
\end{tabular}


5. When I do a good job, I receive the recognition for...

*6. Many of our rules and procedures make doing a good...

7. I like the people I work with.

*8. I sometimes feel my job is meaningless.

9. Communications seem good within this organization.

*10.Raises are too few and far between.

11.Those who do well on the job stand a fair chance of...

*12.My supervisor is unfair to me.

13.The benefits we receive are as good as most other...

*14.I do not feel that the work I do is appreciated.

15.My efforts to do a good job are seldom blocked by...

*16.I find I have to work harder at my job because of...

17. I like doing the things I do at work.

*18. The goals of this organization are not clear to me.

*19. I feel unappreciated by the organization when I...

20. People get ahead as fast here as they do in other...

*21. My supervisor shows too little interest in the...

22. The benefit package we have is equitable.

$* 23$. There are few rewards for those who work here.

*24. I have too much to do at work.

25. I enjoy my coworkers.

*26.I often feel that I do not know what is going on with...

27.I feel a sense of pride in doing my job.

28.I feel satisfied with my chances for salary increases.

*29.There are benefits we do not have which we should...

30.I like my supervisor.

*31.I have too much paperwork.

*32.I don't feel my efforts are rewarded the way they...

33.I am satisfied with my chances for promotion.

*34.There is too much bickering and fighting at work.

35.My job is enjoyable.

*36. Work assignments are not fully explained.
Somewhat Satisfied

Somewhat Dissatisfied

Very Satisfied

Very Satisfied

Somewhat Satisfied

Somewhat Satisfied

Somewhat Satisfied

Very Satisfied

Very Satisfied

Somewhat Satisfied

Somewhat Dissatisfied

Very Satisfied

Very Satisfied

Somewhat Satisfied

Very Satisfied

Somewhat Dissatisfied

Somewhat Satisfied

Somewhat Satisfied

Somewhat Satisfied

Somewhat Dissatisfied

Very Satisfied

Somewhat Satisfied

Very Satisfied

Somewhat Satisfied

Somewhat Dissatisfied

Very Satisfied

Somewhat Dissatisfied

Somewhat Satisfied

Somewhat Satisfied

Somewhat Satisfied

Very Satisfied

Somewhat Satisfied

$*=$ negatively-worded statements

This table depicts the results of employees' behavior and attitudes towards their job. Results show that their job satisfaction level is "slightly agree" with a composite mean of 4.08. This implies that the respondents are "somewhat satisfied" with their jobs. They are "very satisfied" on 12 items that refer specifically to nature of 
work (4.76), supervision (4.60), and co-workers (4.55); however, they are "somewhat dissatisfied" on 4 items under operating procedures. According to Spector (1994), scores with a mean item response of 4 or more represents satisfaction; hence, the respondents are somewhat satisfied.This result supports with the study of Janardhanan, and George, (2011)and that of Ram (2013).

Table 5. Relationship between Profile and Job Performance

\begin{tabular}{lccccc}
\hline Variables & $\begin{array}{c}\text { Chi-square } \\
\text { test }\end{array}$ & Df & $\begin{array}{c}\text { Critical } \\
\text { value }\end{array}$ & Decision & Result \\
\hline Age & 36.636 & 30 & 43.77 & Insignificant, Ho: Accepted & Not Related \\
Sex & 2.556 & 6 & 12.59 & Insignificant, Ho: Accepted & Not Related \\
Educational Attainment & 17.474 & 15 & 25.00 & Insignificant, Ho: Accepted & Not Related \\
Length of Service & 119.241 & 33 & 47.37 & Significant; Ho: Rejected & Related \\
\hline
\end{tabular}

Results show that age and educational attainment of respondents do not yield a positive relationship with their job performance, since the computed Chi-square values are much lesser than the critical values; hence, the null hypothesis is accepted. This means that whether the employees are young or old, and got higher educational attainment or not, these do not influence their job performance. In other words, their job performance was not affected by their age, sex, and educational credentials.

Nonetheless, their length of work experience is noted to have significantly influenced their job performance. As reflected, the computed value of 119.241 is very much greater than the critical value of 47.37; hence, the null hypothesis is rejected, meaning their length of service here in BISU matters most towards their job performance. It implies further that the higher the length of their service in this institution, the better they perform in their job. Since years of service denotes work attitude maturity, and much skills learned from colleagues and from those experienced ones which added to their better work performance. This result is in accord with the study of Omori, et al, (2019) where years of work experience significantly influenced workers' performance.

Moreover, as to gender, this table shows that it has a negative significant relationship with workers' performance. This result corroborates with the study of Omori, et al., (2019) where both male and female do perform their duties alike, which means that if male and female are given equal opportunities on any tasks performance, there is bound to be a progressive improvement as both can deliver the same.

On the age result, this is corroborated by the study of Hedge and Borman (2012), who argued against age as a determinant factor to performance. They said that age was a very weak predictor of performance.

Table 6. Relationship between Profile and Job Satisfaction

\begin{tabular}{llllll}
\hline Variables & Chi-square test & Df & Critical value & Decision & Result \\
\hline Age & 35.841 & 30 & 43.773 & Insignificant, Ho: Accepted & Not Related \\
Sex & 8.517 & 6 & 12.592 & Insignificant, Ho: Accepted & Not Related \\
Educational Attainment & 22.448 & 15 & 24.996 & Insignificant, Ho: Accepted & Not Related \\
Length of Service & 52.156 & 33 & 47.3685 & Significant, Ho: Rejected & Related \\
\hline
\end{tabular}

As shown in Table 4.2, age, sex, and educational attainment do not result significant relationship towards their job satisfaction where each computed chi-square value is much lesser than the critical value; hence, the null hypothesis is accepted. This means that these demographics, whether young or old, male or female, earned the highest degree or 
not, these do not influence their satisfaction or dissatisfaction of their jobs. This result supports to the study of Amarasena, Ajward, \&Ahasanul Haque, (2015) where gender, age (Sarker, Crossman, \& Chinmeteepituck, 2003; Ram, 2013), academic qualifications (Vasiliki, and Efthymios, 2013).

However, their length of service in BISU and their job satisfaction are positively and significantly correlated, where its computed chi-square test value (52.156) is greater than its critical value (47.3685); hence, the null hypothesis is rejected, which means that their length of service in BISU is a factor towards their job satisfaction. This further implies that the longer their years of service in this institution, the more satisfied they become. It is indicative that experience signifies job promotions and opportunities, and much achievements. Consequently, the employee becomes more satisfied with his chosen profession. This result supports with the studies of Barotik, (2016) and Amburgey (2005) where they noted a significant relationship between job satisfaction and employee experience.

Table 7. Relationship between Levels of Two Variables

\begin{tabular}{lccll}
\hline Variables & Spearman rho test & p-value & Decision & Result \\
\hline Awareness and Job Performance & -0.039 & 0.470 & Insignificant, Ho: Accepted & No Relationship \\
Awareness and Job Satisfaction & 0.099 & 0.065 & Insignificant, Ho: Accepted & No Relationship \\
Implementation and Job Performance & -0.049 & 0.370 & Insignificant, Ho: Accepted & No Relationship \\
Implementation and Job Satisfaction & 0.148 & 0.006 & Significant, Ho: Rejected & Related \\
Job Performance and Job Satisfaction & 0.013 & 0.810 & Insignificant, Ho: Accepted & No Relationship \\
\hline
\end{tabular}

The respondents' awareness of CDP and job performance, awareness and job satisfaction, extent of implementation of CDP and job performance, and job performance and job satisfaction do not yield significant and positive results, as reflected in greater p-values $(0.470$, $0.065,0.370$, and 0.810 , respectively) at $5 \%$ level of significance; hence, the null hypotheses are accepted, meaning one does not influence the other. In other words, whether or not the respondents are aware of CDP, they are still performing their tasks well, and feel satisfied with it; whether such CDP is implemented or not, they still manifest excellence in their work; and that their job performance does not influence their job satisfaction and vice-versa.

However, the extent of implementation and job satisfaction indicate positive and significant relationship, manifesting a much lesser p-value of 0.006 at 0.05 significance level; thus, the null hypothesis is rejected, meaning their perceived extent of implementation of CDP 2012 has influenced their job satisfaction. This implies further that the higher the implementation of CDP, the more satisfied they become. This result connotes the importance of proper and full implementation of any plans and programs beneficial for both employees and the organization for them to be more satisfied with their jobs. This finding supports to the study of Chen, et al. (2004), who found a positive relationship between the career development programs and job satisfaction, and professional development and productivity.

Whether the respondents are very much aware of CDP or not, their performance level in accomplishing their jobs and the extent of their job satisfaction are not affected; whether or not the CDP is highly implemented, their job performance is not influenced; and, that their job performance is not influenced by their positive or negative feelings about their jobs, or their job satisfaction. In short, their satisfaction or dissatisfaction about their jobs has nothing to do with their outstanding or poor performance. This result supports the study of Angeles, Saludo, Virtus, \& Win, (2015) where they found no significant relationship between job satisfaction and performance of Ajinomoto employees, and so with the study of Babirye, (2019), and Ram (2013) implying that high levels of job satisfaction did not necessary lead to employee performance.

\section{CONCLUSION}

The results of this study indicate that BISU employees consider their length of service as contributory factor that would influence their level of job performance and extent of job satisfaction, which implies that the longer 
their work experience here in BISU, the better their work performance would be expected from them, and the more satisfied they are with their jobs. Moreover, there is indeed a need to implement any good career development plans and programs as the respondents believed them as influential and significant factor in their satisfaction and dissatisfaction with their assigned tasks.

\section{REFERENCES}

[1] Al-zawahreh, A. and Madi, F. A. (2012). The Utility of EquityTheory in Enhancing Organizational Effectiveness. European Journal of Economics, Finance and Administrative Sciences.

From researchgate.net/publication/267783009_The_Utility_of_Equi ty_Theory.

[2] Anuar, B.H. (2011). The Relationship between Job Satisfaction and Job Performance among Employee in Trade Winds Group of Companies. From eprints.oum.edu.my/668/1/relationshipanuar.pdf.

[3] Bakotić, D. (2016). Relationship between Job Satisfaction and Organisational Performance, Economic ResearchEkonomskaIstraživanja, 29:1, 118-130, DOI: 10.1080/1331677X.2016.1163946. From tandfonline.com/action/showCitFormats?

[4] Bhatnagar, K. and Srivastava, K. (2012). Job Satisfaction in Health-care Organizations. Indian Psychiatry Journal. doi: 10.4103/0972-6748.110959.

[5] BISU Career Development Plan 2012 Manual. Human Resource Management Office

[6] "Business Jargon". Adam's Equity Theory. From businessjargons.com/adams-equity-theory.html.

[7] Civil Service Commission Executive Order No. 292

[8] Chen, T. Y., Chang, P.L., \& Yeh, C.H. (2004) An Investigation of career development programs, job satisfaction, professional development and productivity: the case of Taiwan, Human Resource Development International, 7:4, 441-463, DOI: 10.1080/1367886042000246049.

[9] DSWD's Memo Circular No. 5, s. 2007. Guidelines in the Implementation of the Career Pathing Program. Retrieved on August 24, 2019 from dswd.gov.ph/issuances/MCs/MC_2007-005.pdf.

[10] Ezeamama, I.G. (2019). Job Satisfaction and Employee Productivity in Anambra State Nigeria. European Journal of Research in Social Sciences Vol. 7 No. 2. From.idpublications.org/wp-content/uploads/2019/01/FullPaper-JOB-STATISFACTION-AND-EMPLOYEEPRODUCTIVITY-IN-ANAMBRA-STATE-

[11] Fogaça, N., Rego, M.C.C.B., Melo, M.C.C., Armond, L. P.,Coelho, F. A. (2018). Job Performance Analysis: Scientific Studies in the Main Journals of Management and Psychology from 2006 to 2015 .
From

/Users/Ramil\%20Bulilan/Downloads/JobPerformanceAnalysi

[12] Gabčanová, I. (2011). The Employees - The Most Important Asset in the Organizations. Human Resources Management \& $\begin{array}{llll}\text { Ergonomics } & \text { Vol. } & \text { V. } & \text { From }\end{array}$ frcatel.fri.uniza.sk/hrme/files/2011/2011_1_03.pdf.

[13] Gustafson, F. (2019). The Importance of Business Implementation. Small Business -Chron.com. Retrieved from smallbusiness.chron.com/importance-businessimplementation-34571.html.

[14] Heathfield, S. M. (2019). "Steps to Create a CareerDevelopment Plan". The balance Career. Retrieved on September 4, 2019 from thebalancecareers.com/steps-tocreate-a-career-development-plan-1917798.

[15] Inuwa, M. (2016). Job Satisfaction and Employee Performance: An Empirical Approach. The Millennium University Journal; Vol. 1, No. 1; ISSN 2225-2533 Published by The Millennium University. Fromresearchgate.net/publication/321966659_Job_S

[16] Jusuf, A. H., Mahfudnurnajamuddin, Mallongi, S., and Latief, B. (2016). The Effect of Career Development, Leadership Style and Organizational Culture on Job Satisfaction and Organizational Commitment. International Journal of Business and Management Invention, Vol.5 Issue 3. From ijbmi.org/papers/Vol (5)3/Version-2/B5030207017.

[17] Khan, F., Rasli, A., Tariq, Rahman, A., \& Khan, M.M. (2014). Job rotation, job performance, organizational commitment: An empiricalstudy on bank employees. Journal of Management Info (JMI). From pdfs.semanticscholar.org/87b4/01eedac56c853ed141841e35

[18] Kosine, N. R. and Lewis, M. V. (2008). Growth and Exploration:Career Development Theory and Programs of Study. Career and Technical Education Research, 33(3), pp. 227-243

from scholar.lib.vt.edu/ejournals/CTER/v33n3/pdf/kosine.pdf

[19] Kumar, M. (2016). Study on Impact of Mentoring on Career Development of Employees. BIMS International Journal of Social Science Research, ISSN 2455-4839. From informaticsjournals.com/index.php/bims/article/viewF

[20] Mulder, P. (2018). Super's Life Career Rainbow. FromToolsHero: www.toolshero.com/psychology/personalhappiness/life-career-rainbow/.

[21] Mutonga, M. W. (2012). Relationship between Quality of Work Life and Employees perceptions of performance at Safaricom's Jambo Contact Center in Nairobi. From erepository.uonbi.ac.ke/bitstream/handle/11295/12949/A

[22] Ng, T. W. H. \& Feldman, D.C. (2009). How Broadly Does Education Contribute to Job Performance? Personnel Psychology, 62, 89-134. $\quad$ From homepages.se.edu/cvonbergen/files/2013/01/How-BroadlyDoes-Education-Contribute-to-Job-Performance.pdf.

[23] Nifa, F.A.A., Chong Khai Lin, C.K., Mardiah, W.N., Rani,W.M., and Wei, O.W. (2018). A Study on Awareness of 
Disaster Risk Reduction (DRR)Among University Students: The Case of PETRONAS Residential Hall students. From aip.scitation.org/doi/pdf/10.1063/1.5055407.

[24] Omori, A. E., and Bassey, P. U. (2019). Demographic Characteristics and Workers' Performance in Public Service in Nigeria. International Journal of Research and Innovation in Social Science (IJRISS) |Volume III, Issue II, ISSN 24546186. From rsisinternational.org/journals/ijriss/DigitalLibrary/volume-3-issue-2/141-f.

[25] Ram, P. (2013). Relationship between Job Satisfaction and Job Performance in the Public Sector-A Case Study fromIndia. International Journal of Academic Research in Economics and Management Sciences, Vol. 2, No. 2. ISSN: 2226-3624, from hrmars.com/admin/pics/1676.pdf.

[26] Republic Act No. 10912, July 21, 2016. From laws.chanrobles.com/republicacts/110_republicacts.php?id=1 0697. An act mandating and strengthening the continuing professional development program.

[27] Sarker, S.J. Crossman, A. and Chinmeteepituck, P. (2003). The Relationships of age and length of service with Job Satisfaction: An Examination of Hotel Employees in Thailand. Journal of Managerial Psychology 18(7). From researchgate.net/publication/233508346_The_relationships_o f_age_and_length_of_service_with_job_satisfaction.

[28] Satar, A., Nawaz, A. and Khan, S. (2012). The contextual impacts on job satisfaction of employees in the developing states like Pakistan. From researchgate.net/publication/283343998_The_contextual_imp acts_on_job_satisfaction_of_employees_in_the_developing_s tates_like_Pakistan.

[29] Shrestha, I. (2019). Influence of Demographic Factors on Job Satisfaction of University Faculties in Nepal. NCC Journal.

[30] Spector, P. E. (1994). Job Satisfaction Survey, JSS. From shell.cas.usf.edu/ pspector/scales/jssovr.html.

[31] Spector, P. E. (1997). Measurement of Human Service Staff Satisfaction: Development of Job Satisfaction Survey.American Journal of Community Psychology, Vol.13, No.6.

From shell.cas.usf.edu/ pspector/scales/ajcp85-jss.pdf.

[32] Shujaat, S., Sana, S., Aftab, F., \&Ahned, I. (2013). mpact of Career Development on Employee Satisfaction in Private Banking Sector Karachi. Journal of Management and Social Sciences, Vol. $\quad 9, \quad$ No. 2. $\quad$ From pdfs.semanticscholar.org/9ea3/2f069b2e7e178db37db1d607d 859

[33] Tan, T. H. and Waheed, A. (2011). Herzberg's MotivationHygiene Theory and Job satisfaction in the MalaysianRetail Sector: The Mediating Effect of Love of Money. Asian Academy of Management Journal, vol.16, no.1. From mpra.ub.uni-muenchen.de/30419/2/MPRA_paper_30419.pdf.

[34] Trueba, J. A. (2008). The Career Development Plan - A Quick Guide for Managers and Supervisors. The National Career Development Association. From
associationdatabase.com/aws/NCDA/pt/sd/news_article/6420/ _PARENT/layout_details/false.

[35] Ugwu, C., and Ugwu, M. E, (2017). Demographic Variables and Job Performance of Librarians in University Libraries in South East Nigeria. Library Philosophy and Practice (ejournal). From digitalcommons.unl.edu/libphilprac/1553.

[36] Usop, A. M., Kadtong, M. L. \&Usop. A. S. O. (2013). The Significant Relationship between Work pperformance and Job Satisfaction in Philippines. International Journal of Human Resource Management and Research (IJHRMR) ISSN 22496874 Vol. 3, Issue 2, (C) TJPRC Pvt. Ltd. From researchgate.net/publication/236017106.

[37] Zin, M. L. M., Shamsudin, F. M., and Subramaniam, C. (2013). Investigating the Influence of Job Rotation on Career Development among Production Workers in Japanese Companies, International Journal of Business and Society, Vol. 14 No. 1, 2013, $135 \quad$ - 148. ijbs.unimas.my/repository/pdf/INVESTIGATING\%20THE\% 20INFLUENCE\%20OF\%20JOB\%20ROTATION\%20pg135148.pdf. 